\title{
The reliability and economic analysis of rainwater harvesting system for commercial building with large rooftop area
}

\author{
Mohamad Ali Fulazzaky ( $\sim$ fulazzaky@unida.ac.id) \\ Universitas Djuanda https://orcid.org/0000-0002-4600-5742 \\ Achmad Syafiuddin \\ Universitas Nahdlatul Ulama Surabaya \\ Martin Roestamy \\ Universitas Djuanda \\ Zulkifli Yusop \\ Universiti Teknologi Malaysia \\ Jonbi Jonbi \\ Universitas Pancasila \\ Dedy Dwi Prasetyo \\ Institut Teknologi Sepuluh Nopember
}

\section{Research Article}

Keywords: commercial building, economic cost-benefit analysis, rainwater harvesting, rainwater storage tank, water management based reliability analysis

Posted Date: November 16th, 2021

DOI: https://doi.org/10.21203/rs.3.rs-1046274/v1

License: (c) (i) This work is licensed under a Creative Commons Attribution 4.0 International License.

Read Full License

Version of Record: A version of this preprint was published at ACS ES\&amp;T Water on March 16th, 2022. See the published version at https://doi.org/10.1021/acsestwater.1c00455. 


\title{
The reliability and economic analysis of rainwater harvesting system for commercial building with large rooftop area
}

\begin{abstract}
The problem of water shortages faced by many countries including the country that having sufficient water source needs to be provided a practical engineering solution. The reliability analysis of rainwater harvesting system (RWHS) installed at the commercial building of AEON Taman Universiti located in Johor Barhu city of Malaysia was based on the rainfall pattern, rainwater use and rainwater storage tank. The economic analysis using the net present value (NPV), return on investment (ROI) and benefit-cost ratio (BCR) was performed to assess the optimal management of RWHS installed during the period of construction and retrofitted after the operation of commercial building. The results showed that the balance of water supply and demand is reliable to implement the RWHS and the optimal management of $1000-\mathrm{m}^{3}$ RWHS tank installed during the construction could be more promising than that retrofitted after the operation of AEON Taman Universiti commercial building. The operation of RWHS installed during the construction of building is obviously more feasible due to the values of NPV, ROI and BCR tend to be high. The reliability and economic analysis of RWHS installed during construction and that retrofitted after operation of commercial building demonstrated the benefit of RWHS installation will contribute to the future of building design for achieving an effective water management.
\end{abstract}

Keywords: commercial building; economic cost-benefit analysis; rainwater harvesting; rainwater storage tank; water management based reliability analysis.

\section{Introduction}

Water shortages can be caused by climate change, increased pollution and increased demand of water and are among the main problems to be faced by many countries including Malaysia. The applicability of the rainfall intensity-duration-frequency curves and parameters for design of rainwater harvesting system (RWHS) could be useful to predict the efficiency of water saving for tropical climate regions (Sendanayake et al., 2014). The variability of tropical rainfall experienced in Uganda cannot meet the need of household water demands in dry season due to the design of an insufficient RWHS tank capacity cannot respond to the competitive use of water placed at risk by poor water management (Bernard \& Joyfred, 2020). The implementation of RWHS continued to have a significant impact on the regional water cycle can reduce the risk of flooding and the cost of municipal drainage system installation and operation (Gado \& El-Agha, 2020). An interbasin water transfer as one of the most attractive alternatives has been suggested for the management strategy of water allocation with using the 24 scenarios to ensure the continuous availability of water in the Dohuk Dam of Dahuk Governorate in Iraq being characterized with its borderline semi-arid and Mediterranean climate for agricultural, domestic and tourism uses (Fulazzaky et al., 2017). A study of the rainwater harvesting focused on the balance between sustainability values and storage capacity showed that the use of proper dam wall heights is able to store enough water for 
agricultural use in Sabor River basin of the north-eastern Portugal (Terêncio et al., 2018). The utilization of harvested water at the Ave River basin in Portugal may replace the need of stream water to irrigate a cropland of 400 ha that consumes 2.69 $\mathrm{Mm}^{3}$ of water per year (Terêncio et al., 2018). The treatment of rainwater as a source of water for drinking-water supply has been proposed using a reliable technique of bio-sand filter (Fulazzaky et al., 2009). The collection of rainwater from roof building area requires a suitable technique to harvest such potential water availability for various independent uses. Rainwater harvesting system (RWHS) is a promising technique and may serve as an alternative water resource for potable and non-potable uses and for reducing flood proneness (Sepehri et al., 2018). This system provides the economic, technological and environmental benefits of water uses greatly outweighed the costs. Several studies have been conducted to evaluate the performance of RWHS operation, each varying in purpose, scope and output. The installation of RWHS targeted for the residential areas in Australia can save an annual domestic cost of up to 240 AUD per house (Tam et al., 2010). The application of RWHS for the number of residential and commercial buildings in South Korea has been proposed as an alternative way to reduce up to $10 \%$ of the detrimental effects of flooding (Kim \& Yoo, 2009). The installation of RWHS in a residential area in Palermo of southern Italy can reduce approximately $35 \%$ of flooded area for a rainfall event with depth up to $50 \mathrm{~mm}$ (Freni \& Liuzzo, 2019). The application of RWHS may delay the construction of new water storage infrastructure because it has a capability to reduce the dependency of water from domestic water supply (Coombes et al. 2002). It is possible to substantially reduce the volume of water storage without loosing substantial efficiency of RWHS if the application is typical of the low demand of harvested rainwater (Sanches Fernandes et al., 2015; Terêncio et al., 2017). An economic analysis revealed that the payback period of RWHS operation at different major cities in Bangladesh varies from 2 to 6 years with reaching up to $40 \%$ of the reliability depending on the dependent variables and climatic conditions (Bashar et al., 2018). The operation of RWHS for certain buildings in the areas of cold semi-arid climates can supply about $70 \%$ of non-potable water (Molaei et al., 2019). The development of RWHS used as an effective alternative water supply can deal with the water scarcity by optimizing the performance of RWHS operation (Dismas et al., 2018; Notaro et al., 2017; Pacheco and Campos, 2016).

Challenges of implementing the RWHS operation for a large rooftop area of building are how to minimize the installation and maintenance costs and how to gain public acceptance of the rainwater uses for various purposes. The management of rainwater harvesting cisterns with the acceptable limits of Palestinian water quality standards has been practiced in southern Palestine (Al-Salaymeh et al., 2011). Understanding the trend of rainwater harvesting market may contribute towards determining the optimum size of RWHS tank taking into consideration of the rainfall patterns in the tropical climates such as in the southwest part of Peninsular Malaysia. The operation and maintenance costs of RWHS may be reduced through the optimization of rainwater storage tank design. Designing the gravity flow of rainwater allowed to condition the water flow through piping system may avoid the utilization of pump to which a condition should be met the payment of electrical tariff. The investment cost of RWHS may be reduced through the selection of the appropriate building materials. Providing the subsidies and tax rebates by the local and central governments are encouraged to promote the installation of RWHS for any large rooftop area of building (Lani et al., 2018a). The public awareness campaigns of RWHS management 
waged by either NGOs or governments can shape public opinion to encourage the interest of community. This may provides significant benefits of involving more ownership and responsibility of the RWHS management by the rainwater users (Hervás-Gámez \& Delgado-Ramos, 2019).

Several studies have reported on the implementation of RWHS for the various large commercial buildings (Chilton et al., 2000; Foo et al., 2017; Matos et al., 2015). The analysis of RWHS performance for the large rooftop areas shows that two underground rainwater tanks are quite effective in wet and average years but requires detailed optimization and financial analysis to maximize the benefits of large rainwater tanks (Imteaz et al., 2011). The requirement of commercial purposes to operate RWHS is driven by the needs for economic rewards or utilities. The various aspects of RWHS economic analysis have been performed to show that the costs associated with the installation and maintenance of the RWHS for six major cities in Bangladesh could be dependent on the topographic and climatic conditions (Bashar et al., 2018). The cost of the infrastructures would be enough to make the costeffectiveness of RWHS operation for a new commercial building located in Braga of the northern Portugal (Matos et al., 2015). The local authorities should maintain the rebate for rainwater tanks fitted in detached houses at ten different locations to gain public acceptance of the RWHS operation in Sydney, Australia (Rahman et al., 2012). The installation of RWHS for commercial building is more likely to get many benefit entitlements compared to that for individual residential houses. Many commercial buildings provide a large rooftop area to possibly collect more rainwater for avoiding a large water bill to pay (Rahman et al., 2014). Even though the installation of RWHS for commercial building can gain many benefits of water uses, an economic analysis of both the RWHS installed during the construction and that retrofitted after the operation of building for commercial purpose needs to be understood. The novelty and contribution of the current study are to predict the supply and demand of water based on the daily rainfall data recorded from 1975 to 2003 and the average daily water consumption monitored at the commercial building in Johor Bahru city of Malaysia during a period of 2013 to 2017 and to clarify the intrinsic value advanced by the cost-benefit analysis of installed and retrofitted RWHS, which have not been reported in the previous studies. Therefore, the aims of this study are (1) to evaluate the rainfall patterns of southwest part of Peninsular Malaysia for getting better understanding on the availability of water in the implementation of RWHS and (2) to perform both the reliability and economic analysis of the installed and retrofitted RWHS performances for commercial building of AEON Taman Universiti in Johor Bahru city of Malaysia.

\section{Materials and methods}

\subsection{Commercial building}

The commercial building of AEON Taman Universiti was selected to represent a large rooftop area of building in the southwest part of Peninsular Malaysia. The AEON Taman Universiti is a shopping mall located in the Johor Bahru city of Malaysia with latitude of $1^{\circ} 32^{\prime} 33.1^{\prime \prime} \mathrm{N}$ and longitude of $103^{\circ} 37^{\prime} 44.1 " \mathrm{E}$, as shown in Figure 1. The rainwater collection from the rooftop area of AEON Taman Universiti building only serves for non-potable water uses. 


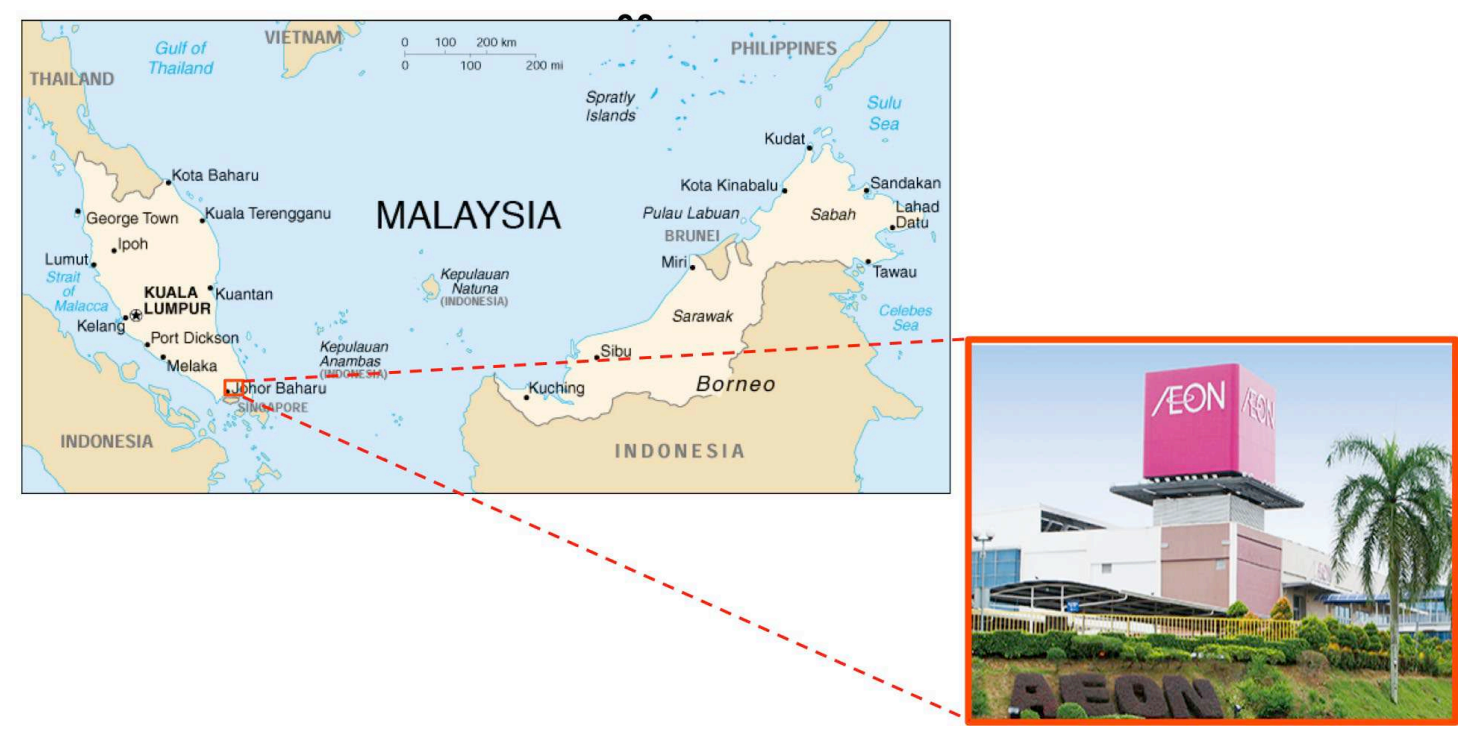

Fig. 1 Location of AEON Taman Universiti commercial building in Johor Bahru city

\subsection{Water consumption}

For the purpose of this work, the average daily consumption of water for commercial building of AEON Taman Universiti was monitored during two years from 2013 to 2014. The monitoring of rainwater uses collected from the rooftop surface of AEON Taman Universiti building includes both the collection of rainwater and the use of rainwater to meet the toilet flushing, plant watering and general cleaning and the purpose of chilled water system. The water consumption data were combined the average daily consumption of water collected from 2013 to 2014 with the water usage for actual portable water used during the billing period of five years $(2013$ - 2017) obtained from the AEON's office.

\subsection{Rainfall patterns}

Long-term daily rainfall data recorded during 29 years from 1975 to 2003 at the Senai International Airport station of Johor state with latitude of $1^{\circ} 38^{\prime} 17.2^{\prime \prime} \mathrm{N}$ and longitude of $103^{\circ} 40^{\prime} 10.3^{\prime \prime} \mathrm{E}$ were used to describe the seasonal and annual variations of rainfall pattern at the location of AEON Taman Universiti commercial building. The complete sets of daily rainfall data with no missing values were used to predict the annual rainfall, number of wet days, percentage of the consecutive dry day occurrence and maximum consecutive dry day. Since the design of RWHS installed at the AEON Taman Universiti building to collect the rainwater does not consider first flush diversion, the potential rainwater harvested can be estimated using the equation (Lizárraga-Mendiola et al., 2015):

$$
P_{\mathrm{h}}=A \times C \times F
$$

where $P_{\mathrm{h}}$ is the potential rainwater harvesting (in $\mathrm{m}^{3}$ ), $A$ is the rooftop area of AEON Taman Universiti building (in $\mathrm{m}^{2}$ ), $C$ is the runoff coefficient (dimensionless) and $F$ is the daily rainfall (in $\mathrm{m}$ ).

\subsection{Data simulation}


Modelling the performance of RWHS has been proposed based on the methods of yield before spillage (YBS) and yield after spillage (YAS). The YAS method yields more conservative estimates of RWHS efficiency by comparing the results obtained from the YAS and YBS models (Park \& Um, 2018). For the purpose of this study, the mass balance model used to predict the capacity of water storage can simulate the rainfall data and is expressed (Hajani \& Rahman, 2014; Raimondi \& Becciu, 2014; Su et al., 2009) as:

$$
O_{t}= \begin{cases}D_{t} & \text { if } V_{t}+V_{i-t} \geq D_{t} \\ V_{t}+V_{i-t} & \text { if } V_{t}+V_{i-t}<D_{t}\end{cases}
$$

where $O_{\mathrm{t}}$ is the daily water released from the RWHS tank (in $\left.\mathrm{m}^{3}\right), D_{\mathrm{t}}$ is the daily water demands for different uses (in $\mathrm{m}^{3}$ ), $V_{\mathrm{t}}$ is the volume of water entered into the RWHS tank (in $\mathrm{m}^{3}$ ) and $V_{\mathrm{i}-\mathrm{t}}$ is the initial volume of water stored in the RWHS tank before entering the volume of $V_{\mathrm{t}}$ collected from a rainfall $\left(\mathrm{in}^{3}\right)$.

The operational reliability of RWHS installed at the commercial building of AEON Taman Universiti can be estimated using the equation (Lani et al., 2018a) of:

$$
R=\frac{o_{t}}{D_{t}} \times 100 \%
$$

where $R$ is the reliability of RWHS operation (in \%), $O_{\mathrm{t}}$ is the daily water released from the RWHS tank (in $\mathrm{m}^{3}$ ), $D_{\mathrm{t}}$ is the daily water demands for different uses (in $\mathrm{m}^{3}$ ).

\subsection{Evaluation of the economic parameters}

This study using three economic parameters of net present value (NPV), return on investment (ROI) and benefit-cost ratio (BCR) for the analysis of RWHS performance to meet the water needs for non-portable uses at the commercial building of AEON Taman Universiti can be expressed respectively in the forms (Morales-Pinzón et al., 2014) of:

$$
\begin{aligned}
& N P V=\sum_{t=0}^{S} \frac{V_{S} \times C_{w}-I_{n}-M_{C}}{(1+r)^{t}} \\
& R O I=\frac{\sum_{i=0}^{s} V_{s} \times C_{w}-I_{n}-M_{c}}{\sum_{i=0}^{s} I_{n}+M_{c}} \\
& B C R=\frac{\sum_{i=0}^{s} \frac{V_{S} \times C_{w}}{(1-r)^{t}}}{\sum_{i=0}^{s} \frac{I_{n}-M_{C}}{(1-r)^{t}}}
\end{aligned}
$$

where $V_{\mathrm{s}}$ is the volume of water saved over the period of time $t\left(\mathrm{in}^{3}\right), C_{\mathrm{w}}$ is the cost of water over the period of time $t$ (in $\left.\mathrm{RM} / \mathrm{m}^{3}\right), I_{\mathrm{n}}$ is the investment required for the period of time $t$ (in $\mathrm{RM}), M_{\mathrm{c}}$ is the maintenance costs over the period of time $t$ (in $\mathrm{RM}$ ), $s$ is the lifespan of RWHS operation (in y), $t$ is the operating period of RWHS installation (in y) and $r$ is the interest rate (in \%).

The annual operational cost can estimated using the equation (Lani et al., 2018a) of:

$$
C_{a}=\frac{V_{a}}{S_{p}} \times E_{p} \times C_{e}
$$


where $C_{\mathrm{a}}$ is the annual operation cost of RWHS (in RM), $V_{\mathrm{a}}$ is the volume of annual water saved by the RWHS operation (in $\mathrm{m}^{3}$ ), $S_{\mathrm{p}}$ is the pump flow speed (in $\mathrm{m}^{3} / \mathrm{h}$ ), $E_{\mathrm{p}}$ is the pump energy used for the RWHS operation (in $\mathrm{kWh}$ ) and $C_{\mathrm{e}}$ is the electricity tariff (in $\mathrm{RM} / \mathrm{kWh}$ ). Noted that the values of $S_{\mathrm{p}}$ and $E_{\mathrm{p}}$ used for the economic analysis of water uses for the commercial building of AEON Taman Universiti were as high as $30 \mathrm{~m}^{3} / \mathrm{h}$ and $2.2 \mathrm{kWh}$, respectively.

By assuming the initial investment for the implementation of RWHS installed at the AEON Taman Universiti commercial building was granted from a loan. The annual year-end payment (annuity) of RWHS installation can be estimated by the equation (Domínguez-Barrero \& López-Laborda, 2012; Kutlu-Koc et al., 2017) of:

$$
C_{a i}=I_{\text {in }}\left[\frac{r(1+r)^{t}}{(1+r)^{t}-1}\right]
$$

where $C_{\text {ai }}$ is the annual year-end payment of the RWHS investment (in RM), $I_{\text {in }}$ is the initial investment for the implementation of RWHS at the commercial building (in $\mathrm{RM}$ ), $r$ is the interest rate (in \%), and $t$ is the time (in y).

The values of the parameters used for the analysis and simulation of the RWHS operation as reported by Lani et al., (2018a) are: $16506 \mathrm{~m}^{2}$ of the rooftop area, 213.9 $\mathrm{m}^{3}$ of the daily water consumption, RM $3.05 / \mathrm{m}^{3}$ of the water tariff, $446 \mathrm{~m}$ of the pipe length, RM 104,600 of the pumping cost; 0.9 of the runoff coefficient, $0.5 \mathrm{RM} / \mathrm{L}$ of the water tank cost, $24.1 \mathrm{RM} / \mathrm{m}$ of the piping cost, $133 \mathrm{RM}$ of the monthly maintenance cost, RM 4,000 of the retrofitting cost per pipe, RM $0.43 / \mathrm{kWh}$ of the electricity tariff, $4.25 \%$ of the average interest rate, $3.05 \mathrm{RM} / \mathrm{m}^{3}$ of the water tariff, 20 $\mathrm{y}$ of the tank replacement, $10 \mathrm{y}$ of the pump replacement and $30 \mathrm{y}$ of the RWHS lifespan.

\section{Results and discussion}

\subsection{Reliability analysis}

\subsubsection{Rainwater pattern}

Rainfall pattern is the important factor affecting the efficiency of RWHS operation at the large rooftop area of building. Effect of the rainfall patterns on the performance of RWHS has been investigated at several locations in the peri-urban regions of Greater Sydney, Australia (Hajani \& Rahman, 2014; Rahman et al., 2012) and in the various European climate zones (Palla et al., 2012). In this work, the daily rainfall data recorded from 1975 to 2003 at the rainfall station of Senai International Airport were used for the analysis of rainfall patterns affected the effectiveness of RWHS installed at the commercial building of AEON Taman Universiti, as shown in Fig. 2. The average and maximum daily rainfall were recorded as high as $11.8 \mathrm{~mm}$ and 364.4 $\mathrm{mm}$, respectively, to show typical rainfall pattern of southern Johor state characterized by a high daily rainfall in December with its maximum daily rainfall occurred on the 2 December 1978. 
(a)

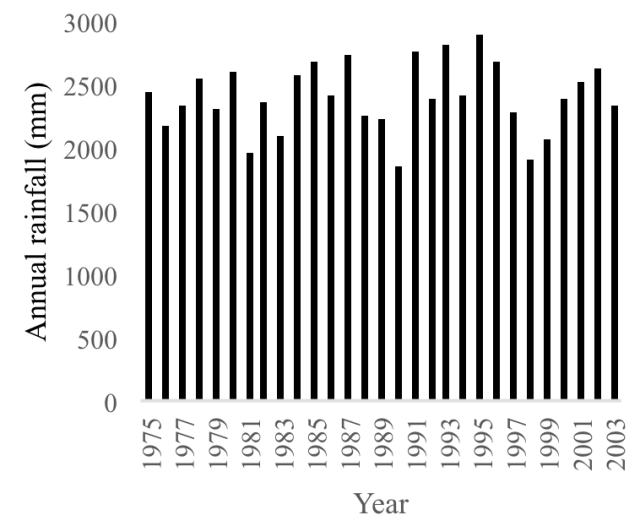

(c)

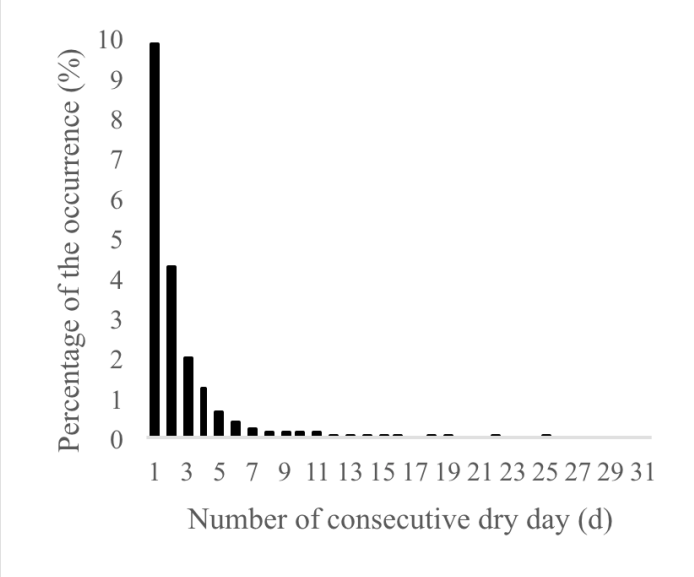

(b)

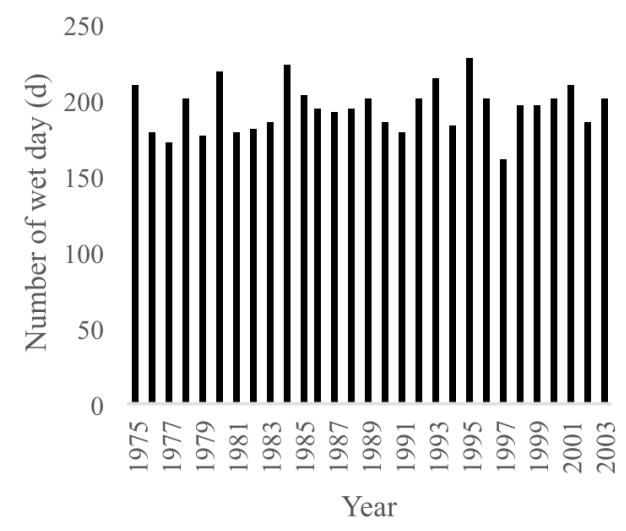

(d)

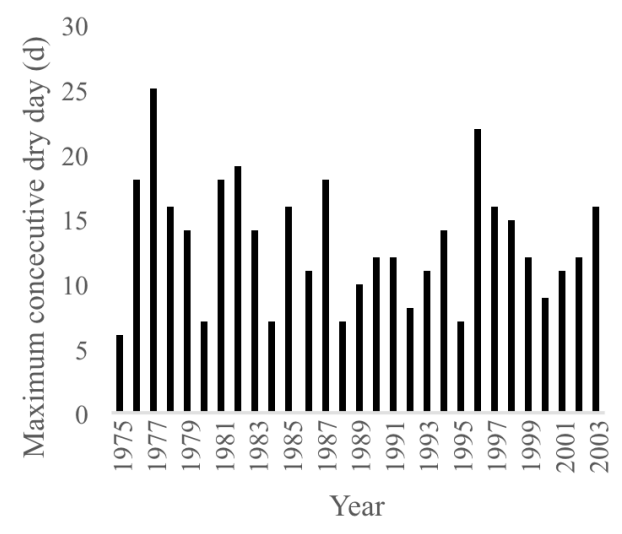

Fig. 2 Rainfall patterns recorded at the rainfall station of Senai International Airport from 1975 to 2003 with (a) annual rainfall, (b) number of wet days, (c) percentage of the occurrence of consecutive dry day and (d) maximum consecutive dry day

The spatial and temporal characteristics of the rainfall over the west region of Malaysia have been divided into five parts of northwest, west, east, southwest and central region of Peninsular Malaysia (Suhaila \& Yusop, 2017). The annual rainfall across the Malaysia country varies over time and space. The rainfall characteristics in time and space of one part are distinctly different from other parts in the Peninsular Malaysia. Statistical distribution of daily rainfall is more regular over the west, northwest and southwest parts compared to the east part of Peninsular Malaysia (Suhaila \& Jemain, 2012). The long-term hydrological data set of daily rainfall consistently collected from a rain gauge and weather station could better help to model the rainfall pattern by taking into account multiple objectives of the RWHS installation (Campisano et al., 2017). Figure 2a shows that the annual rainfall monitored from 1975 to 2003 at the rainfall station of Senai Senai International Airport ranges from 1860.4 to $2891.9 \mathrm{~mm}$. The minimum annual rainfall of 1860.4 mm occurred in 1990 and the maximum annual rainfall of $2891.9 \mathrm{~mm}$ occurred in 1995. In spite of the annual rainfall of below than $2000 \mathrm{~mm}$ was recorded for three years in 1981, 1990 and 1998, the annual rainfall in the southwest part of Peninsular Malaysia can be considered very high. Information regarding the rainfall patterns 
shows an average daily rainfall of $11.8 \mathrm{~mm}$, which is promising to the implemention of RWHS. Analyzing the regional characteristics of rainfall is related to the operation of RWHS installed at the commercial building of AEON Taman Universiti. The implementation of RWHS offers one of the attractive solutions to operate an efficient and successful integrated water resources management (Fulazzaky, 2014).

The characteristics of rainfall for Johor Bahru city that located in the southwest part of Peninsular Malaysia exhibit consistency in the rainfall patterns (Suhaila \& Yusop, 2017). This may have a great opportunity to implement the RWHS collection of rainwater at any reliable building of having a large rooftop area. The number of rainy days in Johor Bahru city as shown in Fig. 2b ranges from 160 to 228 days with an average of 195 days associated with the contribution of heavy rainfall events to total annual precipitation. The implementation of RWHS as an alternative water resource has been successful in Singapore and Indonesia (Alexander et al., 2006; As-syakur, 2013) but is still very limited due to the time of ROI is long and the public acceptance is still poor. The implementation of RWHS becoming more attractive in the Johor state of Malaysia may help reduce the water bill since the Johor's water tariff is already among the highest water tariffs in the country. The economic analysis of RWHS installation to collect the rainwater from commercial building of AEON Taman Universiti is important to understand the exact condition of economy that covers a number of the water management issues.

Understanding the number of consecutive dry day within a period of 29 years could be useful in designing the proper volume of RWHS tank for commercial building of AEON Taman Universiti. The results (Fig. 2c) of recording the number of consecutive dry day at the rainfall station of Senai International Airport showed that evidence from 1044 dry day events per 10592 days of the rainfall patterns observed during 29 years is approximately $9.86 \%$ of the total observation days. The use of this evidence could be useful to evaluate the various factors affecting the length of dry period and the effect of current dry days on the design of RWHS tank. The selection of proper RWHS tank to collect the rainwater from the rooftop area of AEON Taman Universiti building was simulated using the different economic parameters for the size of RWHS tank in the range of 200 to $2000 \mathrm{~m}^{3}$ (Lani et al., 2018b). An annual basis of recording dry days (see Fig. 2d) showed that the maximum consecutive dry day within a year ranges from 6 days in 1975 to 25 days in 1977. A study conducted by the National Hydraulic Research Institute of Malaysia over the 60-year period at the rainfall station of Ladang Senai showed that the longest consecutive dry days of 40 days were evident in the southwest part of Peninsular Malaysia (Wong et al., 2016). The optimum capacity of RWHS tank can be predicted based on the annual and seasonal distribution pattern of rainfall in the region (Saeedi \& Goodarzi, 2020). Longer consecutive dry days require larger volume of RWHS tank to ensure an effective RWHS operation to collect sufficient rainwater for use in the various purposes during the periods of dry days within a year. The average annual watersaving of RWHS operation has a strong correlation with the average annual rainfall (Hajani \& Rahman, 2014).

\subsubsection{Rainwater use}

The performance of RWHS installed at a building is dependent on the types of rainwater use and the total amount of water withdrawn from the RWHS tank. This 
study considered the types of rainwater use based on the existing pipe distribution system of AEON Taman Universiti building that the non-potable uses of water released in the RWHS tank include the toilet flushing, plant watering and general cleaning, and chilled-water systems. The variation of flush toilet use is in the range of 1587 to $2012 \mathrm{~m}^{3} /$ month with an average of $1834 \mathrm{~m}^{3} /$ month and is approximately $28.6 \%$ of total non-potable water use (see Fig. 3, line-i). The use of rainwater from the RWHS installed at the dormitories located in Poland and Slovakia for toilet flushing reaches approximately $18 \%$ and $29 \%$, respectively, of water saving (Stec \& Zelenáková, 2019). The water-use variation in the indoor and outdoor plant watering and general cleaning is in the range of 793 to $1006 \mathrm{~m}^{3} /$ month with an average of 917 $\mathrm{m}^{3} /$ month and is related to approximately $14.3 \%$ of total non-potable water use (see Fig. 3, line-ii). The use of water for chiller systems installed at the AEON Taman Universiti building is in the range of 3175.0 to $4024.8 \mathrm{~m}^{3} / \mathrm{month}$ with an average of $3667.9 \mathrm{~m}^{3} /$ month and reaches approximately $57.1 \%$ of total non-potable water use (see Fig. 3, line-iii). The quantity of water used to operate the chilled-water systems is approximately two times higher than that for toilet flushing. The amount of water used to flush the toilets is approximately two times higher than that to water the plants and to use for general cleaning. It has been reported that the cost of constructing a RWHS at the commercial building could be significantly lower than the cost of either reusing a treated domestic and industrial wastewater or desalinating seawater (Liaw \& Chiang, 2014). The reliability and cost analysis of the RWHS installed at the commercial building of AEON Taman Universiti is required to provide an insight on the implementation of RWHS for other large rooftop areas in the southwest part of Peninsular Malaysia.

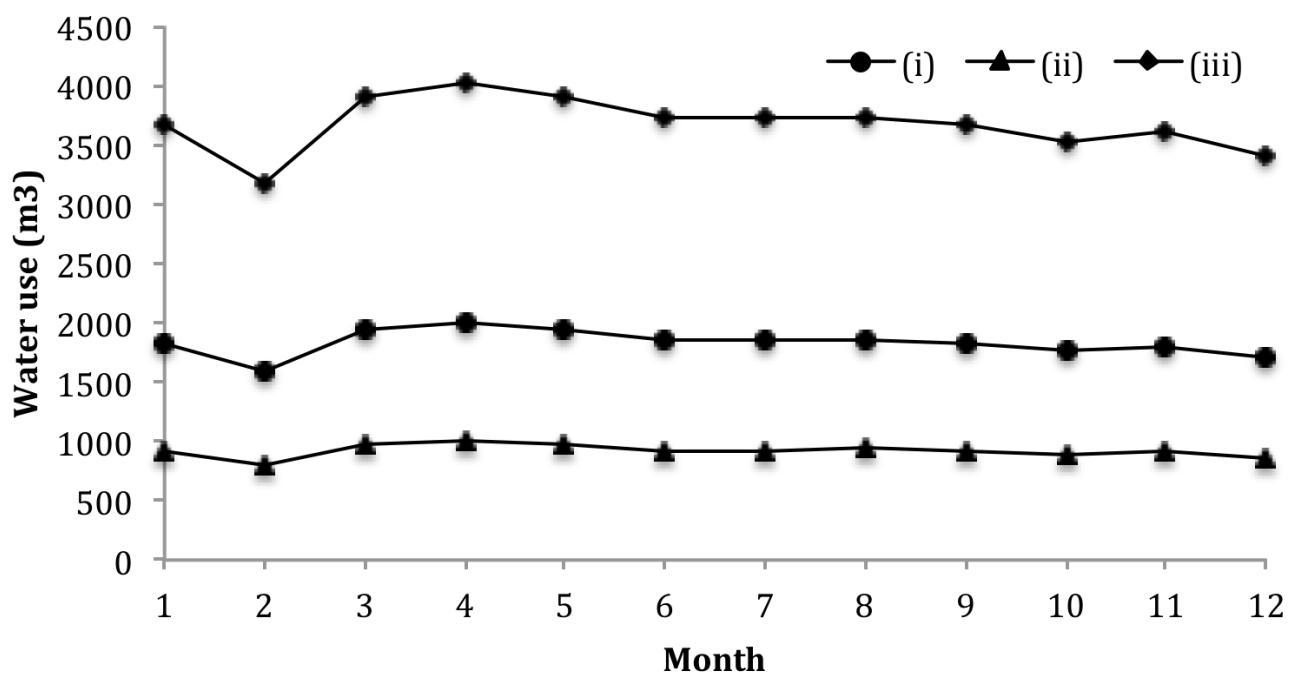

Fig. 3 Average monthly water usage of RWHS installed at the commercial building of AEON Taman Universiti in Johor Bahru city of Malaysia with (i) toilet flushing, (ii) plat watering and general cleaning and (iii) chilled-water system

\subsubsection{Rainwater storage tank}

Several studies have revealed that the reliability analysis of RWHS performance should consider multiple criteria for selecting the optimal design of rainwater storage tank (see Table 1). The reliability of rainwater collected from the various rooftop 
areas and overflow ratio of several RWHS tank sizes have been analysed at different climatic conditions in the cities of Rasht, Sari, Tabriz and Yazd in Iran (Shokati et al., 2020). The rational reliability of rainwater supply for different uses and the most satisfactory storage capacity of any specific rooftop areas can be estimated using a simulation model (Liaw \& Tsai, 2004).

Table 1 Comparing the RWHS performance between current study and various literatures

\begin{tabular}{|c|c|c|c|}
\hline Topic & Location & Significance & Reference \\
\hline $\begin{array}{l}\text { Payback period } \\
\text { analysis of the } \\
\text { RWHs installation }\end{array}$ & $\begin{array}{l}\text { A case study of the } \\
\text { commercial building } \\
\text { in the UK }\end{array}$ & $\begin{array}{l}\text { By considering the effects of } \\
\text { alternative roof and tank } \\
\text { sizes can achieve the length } \\
\text { of time necessary for a } \\
\text { payback period }\end{array}$ & $\begin{array}{l}\text { Chilton et al. } \\
(2000)\end{array}$ \\
\hline $\begin{array}{l}\text { Environmental } \\
\text { management of the } \\
\text { RWHS installation }\end{array}$ & $\begin{array}{l}100 \text { cisterns in } \\
\text { Southern Palestine }\end{array}$ & $\begin{array}{l}\text { Different remediation } \\
\text { measures are recommended } \\
\text { to enhance and protect the } \\
\text { cistern water quality }\end{array}$ & $\begin{array}{l}\text { Al-Salaymeh et } \\
\text { al., (2011) }\end{array}$ \\
\hline $\begin{array}{l}\text { Economic and } \\
\text { sensitivity analysis } \\
\text { of design, cost and } \\
\text { water service } \\
\text { charge }\end{array}$ & $\begin{array}{l}\text { An evaluation of the } \\
\text { tank capacity of } \\
\text { RWHS in South } \\
\text { Korea }\end{array}$ & $\begin{array}{l}\text { An increase in the rate of } \\
\text { water service charge has a } \\
\text { considerable impact on the } \\
\text { economic feasibility }\end{array}$ & $\begin{array}{l}\text { Mun et al., } \\
(2012)\end{array}$ \\
\hline $\begin{array}{l}\text { Water balance } \\
\text { simulation of } \\
\text { RWHS used } \\
\text { different tank sizes }\end{array}$ & $\begin{array}{l}10 \text { locations in } \\
\text { Greater Sydney, } \\
\text { Australia }\end{array}$ & $\begin{array}{l}\text { Increasing a rebate for the } \\
\text { implementation of RWHS } \\
\text { may enhance the public } \\
\text { acceptance }\end{array}$ & $\begin{array}{l}\text { Rahman et al., } \\
\text { (2012) }\end{array}$ \\
\hline $\begin{array}{l}\text { Life cycle cost } \\
\text { analysis using the } \\
\text { ERain tool }\end{array}$ & $\begin{array}{l}\text { A case study of } \\
\text { Australia and Kenya }\end{array}$ & $\begin{array}{l}\text { A rebate that matches tank } \\
\text { size may encourage the } \\
\text { installation of larger tank to } \\
\text { increase water security }\end{array}$ & $\begin{array}{l}\text { Amos et al., } \\
(2018)\end{array}$ \\
\hline $\begin{array}{l}\text { Payback period } \\
\text { analysis of } \\
\text { different RWHS } \\
\text { installations }\end{array}$ & $\begin{array}{l}\text { Six major cities of } \\
\text { the Bangladesh }\end{array}$ & $\begin{array}{l}\text { The costs associated with the } \\
\text { installation and maintenance } \\
\text { of RWHS depend on the } \\
\text { topographic and climatic } \\
\text { conditions }\end{array}$ & $\begin{array}{l}\text { Bashar et al., } \\
(2018)\end{array}$ \\
\hline $\begin{array}{l}\text { Effectiveness of } \\
\text { RWHS to reduce a } \\
\text { flood risk }\end{array}$ & $\begin{array}{l}\text { More than } 400 \\
\text { houses in a } \\
\text { residential area of } \\
\text { Sicily in Southern } \\
\text { Italy }\end{array}$ & $\begin{array}{l}\text { The potential of RWHS in } \\
\text { the mitigation of flood risk is } \\
\text { related to rainfall amount }\end{array}$ & $\begin{array}{l}\text { Freni and } \\
\text { Liuzzo (2019) }\end{array}$ \\
\hline $\begin{array}{l}\text { The reliability and } \\
\text { economic analysis } \\
\text { of RWHS installed } \\
\text { at a large rooftop } \\
\text { area }\end{array}$ & $\begin{array}{l}\text { One commercial } \\
\text { building in Johor } \\
\text { Bahru, Malaysia }\end{array}$ & $\begin{array}{l}\text { The operation of RWHS } \\
\text { installed during the } \\
\text { construction is more feasible } \\
\text { than that retrofitted after } \\
\text { building operation }\end{array}$ & This work \\
\hline
\end{tabular}

The results (Fig. 4) of this study show the daily reliability of rainwater stored in the various RWHS tank volumes of 200, 300, 400, 500 and $1000 \mathrm{~m}^{3}$. The black curves in Fig. 4 refer to the percentage of rainwater reliability while the red curves referred to 
the percentage of rainwater don't meet the daily water demands. The percentage of rainwater that does not provide a sufficient amount of water to meet the daily water demands can gradually decrease with increasing of the RWHS tank volume from 200 to 300 to 400 to 500 and to $1000 \mathrm{~m}^{3}$ (see Figs. 4a, b, c, d, e). The empty tank during a period of 165 days can be simulated to an effective RWHS tank volume of $200 \mathrm{~m}^{3}$ designed to collect the rainwater from the rooftop area of AEON Taman Universiti building. The empty tanks of RWHS operation during the periods of 120,86, 64 and 9 days can be simulated to the storage tank volumes of $300,400,500$ and $1000 \mathrm{~m}^{3}$, respectively. An increase in the volume of RWHS tank from 200 to $300 \mathrm{~m}^{3}$ can reduce the days of empty tank by $27.3 \%$ from 165 to 120 days. A change in the storage tank volume from 200 to $400 \mathrm{~m}^{3}$ can reduce the days of empty tank by $47.9 \%$ from 165 to 86 days. A design of storage RWHS tank capacity could be dependent on the length of the dry periods (Abbas et al., 2021).

(a)

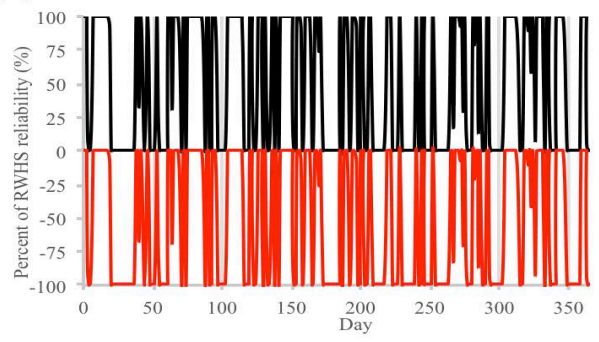

(c)

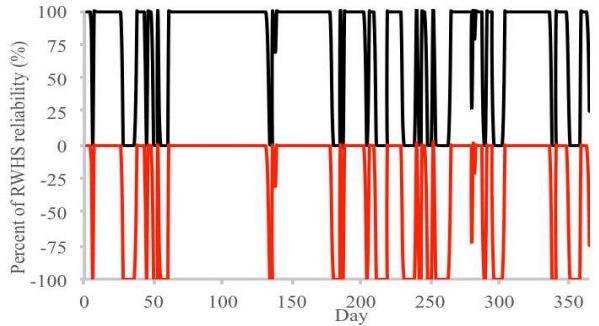

(e)

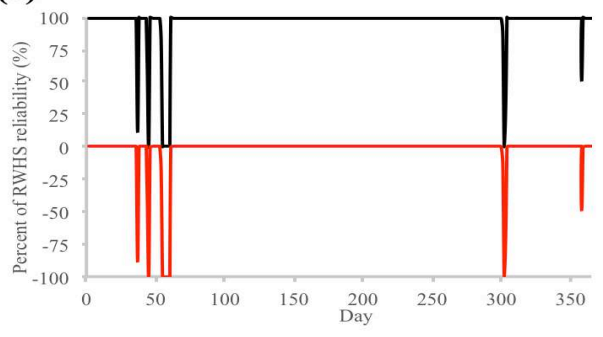

(b)

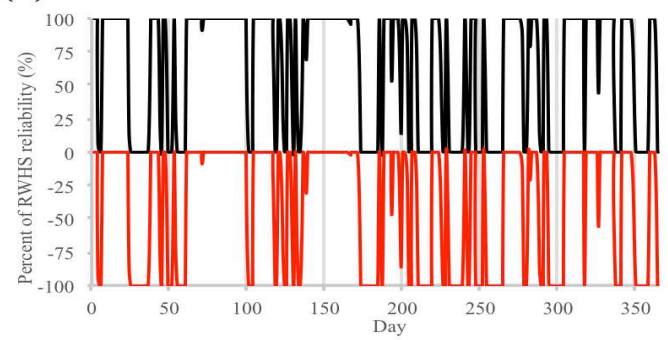

(d)

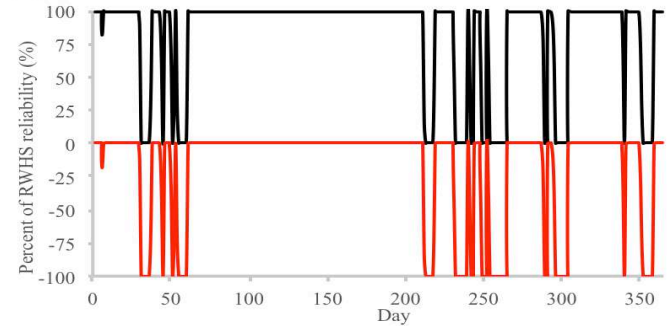

Fig. 4 Daily reliability of rainwater stored in (a) $200 \mathrm{~m}^{3}$, (b) $300 \mathrm{~m}^{3}$, (c) $400 \mathrm{~m}^{3}$, (d) $500 \mathrm{~m}^{3}$ and (e) $1000 \mathrm{~m}^{3}$ of the RWHS tank, where black line refers to percentage of rainwater reliability while red line referred to percentage of rainwater does not meet daily water demands

By increasing the volume of RWHS tank from 200 to $500 \mathrm{~m}^{3}$ can reduce $61.2 \%$ of the days of empty tank from 165 to 64 days. An increase in the volume of RWHS tank from 200 to $1000 \mathrm{~m}^{3}$ can reduce $94.5 \%$ of the days of empty tank from 165 to 9 days. The maximal reliability of $1000-\mathrm{m}^{3}$ storage tank size is promising to collect the rainwater from the rooftop area of AEON Taman Universiti building within one year of water uses due to the size of tank volume increased up to $2000 \mathrm{~m}^{3}$ cannot further 
increase the percentage of rainwater reliability stored in the RWHS tank. In a previous study has been reported that the reliability of RWHS tank larger than $2.6 \mathrm{~m}^{3}$ could be independent of the tank size while a maximum reliability of $10-\mathrm{m}^{3}$ RWHS tank collecting rainwater from a rooftop area of $300 \mathrm{~m}^{2}$ with a daily water demand of $0.3 \mathrm{~m}^{3}$ is approximately $70 \%$ of the total days of the year (Molaei et al., 2020). The detailed assessment of different cistern sizes is required to minimise over-sizing of the RWHS tank and to build a confidence in the RWHS performance (Ward et al., 2012). The economic analysis of RWHS used the ERain analysis tool shows that a rebate should be matched with the tank volume size for getting a good initiative to encourage the installation of larger tanks to improve the water security (Amos et al., 2019).

\subsection{Economic cost-benefit analysis}

\subsubsection{Analysis of the net present value}

Even though the economic cost-benefit analysis of using the various models to provide insights on the optimal management of RWHS installation has been reported in the literatures (see Table 1), the performance and economic analysis by comparing the RWHS installed during the construction and that retrofitted after the operation of commercial building with a large rooftop area needs to be understood. Financial feasibility of RWHS for urban water management at the household scale has been analysed based on a questionnaire survey with 35 households in the Bucaramanga city of Colombia (Oviedo-Ocaña et al., 2018). Perceptions of the official experts and public respondents towards the implementation of RWHS explored for six cities in Iran can reduce the water bills and water shortage crisis (Sheikh, 2020). The use of simulated RWHS tank volume in the range of 200 to $2000 \mathrm{~m}^{3}$ has been normalised with the available rainwater based on the rainfall pattern in the southwest part of Peninsular Malaysia. The uncertainty analysis of model results for the economic assessment of RWHS performance was based on the current water tariff of 3.0 $\mathrm{RM} / \mathrm{m}^{3}$ and the predicted water tariffs of 4.0 and $4.7 \mathrm{RM} / \mathrm{m}^{3}$ in the next 10 and 20 years, respectively, charged to costumers of Johor Bahru city as reported in a previous study (Lani et al., 2018a). In this work, the analysis (Fig. 5) of NPV for the RWHS installed during construction of AEON Taman Universiti building shows that the NPV level of RWHS investment project increased by 345735.3 RM from 271277.4 to $617012.7 \mathrm{RM}$ with a water tariff of $3.0 \mathrm{RM} / \mathrm{m}^{3}$ (see Fig. 5a, line-i), by $548142 \mathrm{RM}$ from 523333.3 to $1071475.3 \mathrm{RM}$ with a water tariff of $4.0 \mathrm{RM} / \mathrm{m}^{3}$ (see Fig. 5b, line-i) and by 681441.9 RM from 681629.2 to $1363071.1 \mathrm{RM}$ with a water tariff of $4.7 \mathrm{RM} / \mathrm{m}^{3}$ (see Fig. 5c, line-i) could be due to an increased volume of the RWHS tank from 200 to $600 \mathrm{~m}^{3}$, from 200 to $700 \mathrm{~m}^{3}$ and from 200 to $800 \mathrm{~m}^{3}$, respectively. The implementation of RWHS can generate important economic benefits with a 5-year of investment amortization and 5,048.3 USD of the NPV level for a transportation logistics company located in the city of Mexico (Zavala et al., 2018). 
(a)

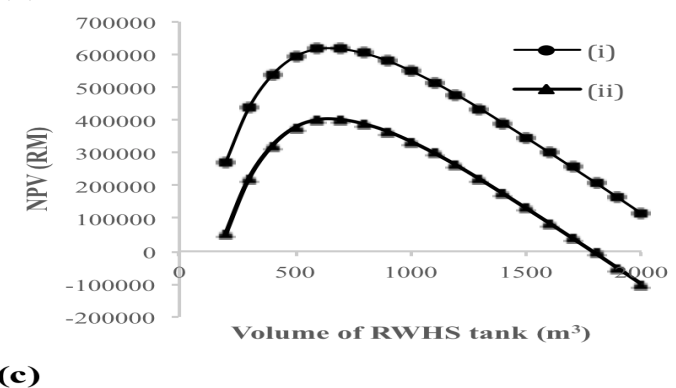

(c)

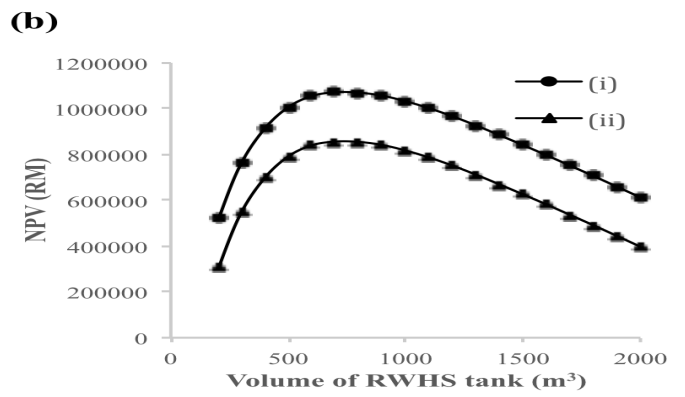

Fig. 5 Analysis of NPV for (i) the RWHS installed during the construction of building and (ii) the RWHS retrofitted after the building operation with the water tariffs of (a) $3.0 \mathrm{RM} / \mathrm{m}^{3}$, (b) $4.0 \mathrm{RM} / \mathrm{m}^{3}$ and (c) $4.7 \mathrm{RM} / \mathrm{m}^{3}$

The NPV level for the RWHS retrofitted after the building operation increased by $345735.3 \mathrm{RM}$ from 56150.5 to $401885.8 \mathrm{RM}$ with a water tariff of $3.0 \mathrm{RM} / \mathrm{m}^{3}$ (see Fig. 5a, line-ii), by 548142 RM from 308206.4 to $856348.4 \mathrm{RM}$ with a water tariff of 4.0 RM/m ${ }^{3}$ (see Fig. 5b, line-ii) and by $681441.9 \mathrm{RM}$ from 466502.3 to 1147944.2 $\mathrm{RM}$ with a water tariff of $4.7 \mathrm{RM} / \mathrm{m}^{3}$ (see Fig. 5c, line-ii) could be due to an increased volume of the RWHS tank from 200 to $600 \mathrm{~m}^{3}$, from 200 to $700 \mathrm{~m}^{3}$ and from 200 to $800 \mathrm{~m}^{3}$, respectively. The level of NPV progressively decreases with increasing up to $2000 \mathrm{~m}^{3}$ of the RWHS tank volume after reaching a maximum level. The highest NPV level for the RWHS installed during the construction of building compared to that for the RWHS retrofitted after the building operation increases by $53.53 \%$ for a water tariff of $3.0 \mathrm{RM} / \mathrm{m}^{3}$ (see Fig. $5 \mathrm{a}$ ), by $25.12 \%$ for a water tariff of $4.0 \mathrm{RM} / \mathrm{m}^{3}$ (see Fig. 5b) and by $18.74 \%$ for a water tariff of $4.7 \mathrm{RM} / \mathrm{m}^{3}$ (see Fig. 5c). Installation of RWHS during the construction of commercial buildings has more benefits since it can reduce a high cost incurred during the installation of RWHS retrofitted after the operation of commercial building for the various business activities (Farreny et al., 2011). Resetting the energy and water systems of commercial building determined an increased cost of RWHS investment retrofitted after operation of building. The arrangement of demolition debris and construction waste disposal requires a significant cost of the RWHS retrofitted after the building operation (Turkyilmaz et al., 2019). The payment of water bills led to an increased cost of the RWHS retrofitted after the operation of building could be one of the economic factors reduced the value of NPV. The results of NPV analysis revealed that the RWHS installed during construction of building could be economically better than that retrofitted after the operation of AEON Taman Universiti building for all simulated volumes of RWHS tank and support the finding of previous study on a neighbourhood of dense social housing located in the Granollers city of Spain (Farreny et al., 2011).

\subsubsection{Analysis of the return on investment}


Performance of the RWHS operation was evaluated using the ROI analysis for the various sizes of rainwater storage tank and different water tariffs, as shown in Fig. 6. By assuming a water tariff of $3.0 \mathrm{RM} / \mathrm{m}^{3}$, the value of ROI increased by 0.38 from 0.53 to 0.91 (see Fig. 6a, line-i) for the RWHS installed during construction higher that increased by 0.37 from 0.06 to 0.43 (see Fig. 6a, line-ii) for the RWHS retrofitted after building operation could be due to an increased volume of the RWHS tank from 200 to $500 \mathrm{~m}^{3}$. The effects of rainfall pattern, geographic aspects, regulation, financial, population and social attributes of the southwest part of Peninsular Malaysia may contribute to the cost of RWHS installation (Plappally \& Lienhard V, 2013). By assuming a water tariff of $4.0 \mathrm{RM} / \mathrm{m}^{3}$, the value of ROI increased by 0.51 from 1.05 to 1.56 (see Fig. 6b, line-i) for the RWHS installed during building construction higher that increased by 0.49 from 0.42 to 0.91 (see Fig. 6b, line-ii) for the RWHS retrofitted after building operation could be due to an increased volume of the rainwater storage tank from 200 to $500 \mathrm{~m}^{3}$. The implementation of RWHS with a storage tank of $500 \mathrm{~m}^{3}$ retrofitted at AEON Taman Universiti building by increasing the water tariff from 3.0 to $4.0 \mathrm{RM} / \mathrm{m}^{3}$ can increase the value of ROI by 0.48 from 0.43 to 0.91 (see Figs. $6 \mathrm{a}, \mathrm{b}$ ) but the water tariff of $4.0-\mathrm{RM} / \mathrm{m}^{3}$ is still not attractive due to the ROI value is less than 1. The application of suitable RWHS tank sizes collected rainwater as an economical option for households in Gold Coast, Brisbane and Sydney has been recommended for different household environments (Tam et al., 2010). The implementation of RWHS retrofitted after commercial building operation is not recommended at the water tariffs of 3.0 and $4.0 \mathrm{RM} / \mathrm{m}^{3}$ because the variation of ROI value pursuant to increased volume of rainwater storage tank is still below than 1 (see Figs. 6a, b). An application of the RWHS to the old town of Lipari in the Aeolian islands of Italy showed the potential water savings of $30-50 \%$ per year with its ROI of less than 15 years (Campisano et al., 2017).

(a)

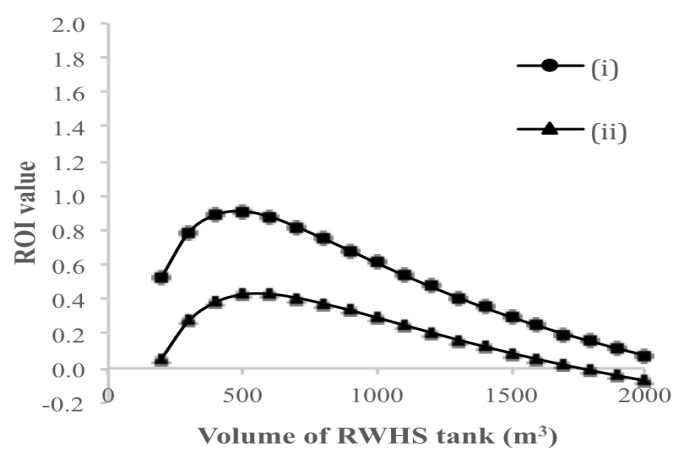

(c)

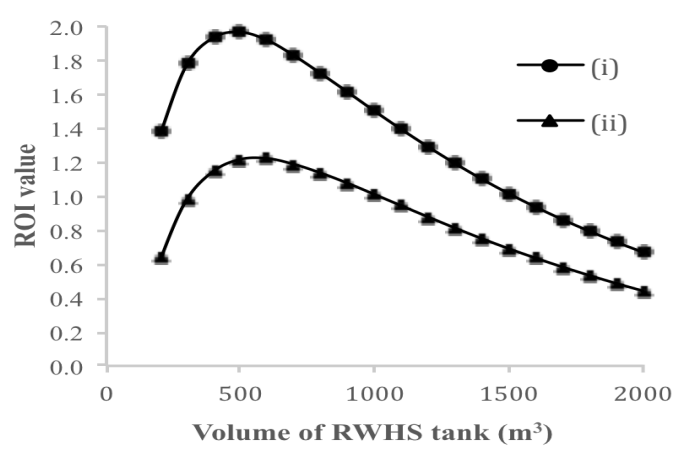

(b)

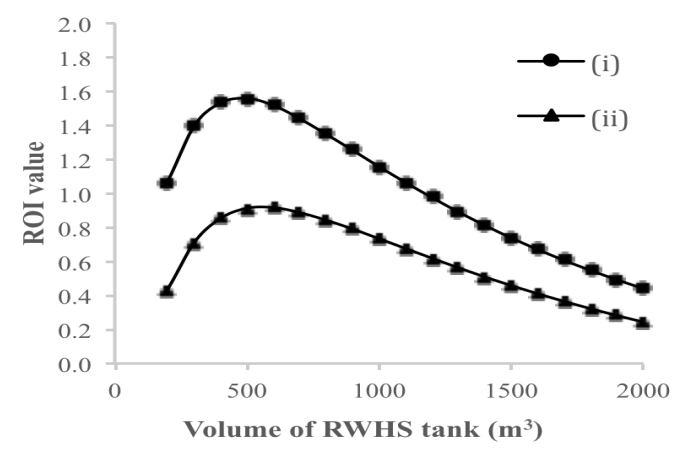


Fig. 6 Analysis of ROI for (i) the RWHS installed during the construction of building and (ii) the RWHS retrofitted after the building operation with the water tariffs of (a) 3.0 RM/m $/ \mathrm{m}^{3}$, (b) $4.0 \mathrm{RM} / \mathrm{m}^{3}$ and (c) $4.7 \mathrm{RM} / \mathrm{m}^{3}$

By assuming a water tariff of $4.7 \mathrm{RM} / \mathrm{m}^{3}$, the ROI of RWHS installed during construction increased by 0.58 from 1.38 to 1.96 (see Fig. 6c, line-i) higher than that retrofitted after operation of building increased by 0.57 from 0.65 to 1.22 (see Fig. 6c, line-ii) could be due to an increased volume of the RWHS tank from 200 to $500 \mathrm{~m}^{3}$. The analysis of ROI revealed that the RWHS retrofitted after operation of AEON Taman Universiti building can justify at the water tariffs of higher than $4.7 \mathrm{RM} / \mathrm{m}^{3}$ due to the ROI of higher than 1 was verified for the volume of RWHS tank in the range of 400 to $1000 \mathrm{~m}^{3}$ (see Fig. 6c, line-ii). This is agreed with a previous study that the benefits of RWHS implementation for commercial buildings are more rewarding since the business operations can be charged at a higher water tariff (Farreny et al., 2011). The RWHS installed during the construction is promising rather than that retrofitted after the operation of AEON Taman Universiti commercial building. The investment of RWHS under a rather unfavourable climate with poor rainfall distribution along the year is very low risk and has a short payback time (Lopes et al., 2017).

\subsubsection{Analysis of the benefit-cost ratio}

An investigation of RWHS operation using the economic performance indicators can estimate the optimal sizing requirements of rainwater storage tank and the connectivity of the storage tank with corresponding rooftop area (Umapathi et al., 2019). The BCR analysis of RWHS installed during construction and that retrofitted after operation of AEON Taman Universiti commercial building are depicted in Fig. 7. The BCR of RWHS installed during the construction of commercial building increased by 0.37 from 1.58 to 1.95 with charged a water tariff of $3.0 \mathrm{RM} / \mathrm{m}^{3}$ (see Fig. 7a, line-i), by 0.50 from 2.11 to 2.61 with a water tariff of $4.0 \mathrm{RM} / \mathrm{m}^{3}$ (see Fig. $7 \mathrm{~b}$, line-i) and by 0.58 from 2.45 to 3.03 with a water tariff of $4.7 \mathrm{RM} / \mathrm{m}^{3}$ (see Fig. $7 \mathrm{c}$, line-i) could be due to an increased volume of the RWHS tank from 200 to $500 \mathrm{~m}^{3}$. The potential volume of rainwater captured annually depending on the cistern size of RWHS used in densely urbanized watershed of such as in southern California allowing the modest economic benefits of high installation and maintenance costs required to pipe the water indoors for outdoor/indoor uses can be evaluated by considering the total water needs of commercial building (Dallman et al., 2016). The BCR of RWHS retrofitted after the building operation increased by 0.37 from 1.08 to 1.45 with charged a water tariff of $3.0 \mathrm{RM} / \mathrm{m}^{3}$ (see Fig. 7a, line-ii), by 0.49 from 1.45 to 1.94 with a water tariff of $4.0 \mathrm{RM} / \mathrm{m}^{3}$ (see Fig. $7 \mathrm{~b}$, line-ii) and by 0.57 from 1.68 to 2.25 with a water tariff of $4.7 \mathrm{RM} / \mathrm{m}^{3}$ (see Fig. 7c, line-ii) is due to an increased volume of the RWHS tank from 200 to $500 \mathrm{~m}^{3}$. The BCR value of RWHS installed with a little cost can improve with increasing of the water demand if the optimal use of RWHS tank has been predicted (Mun et al., 2012). 
(a)

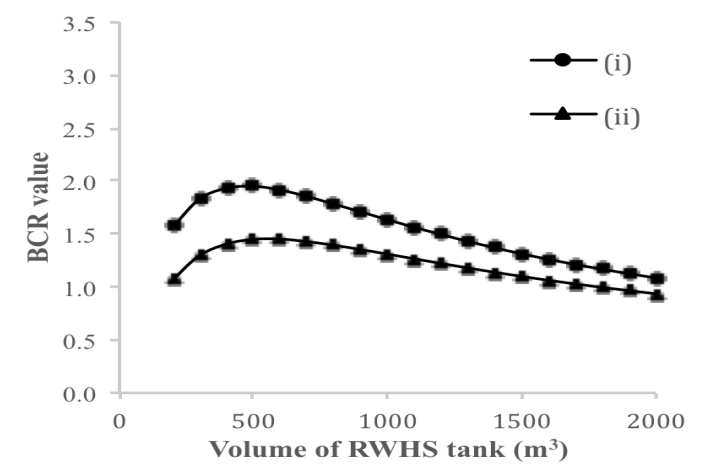

(c)

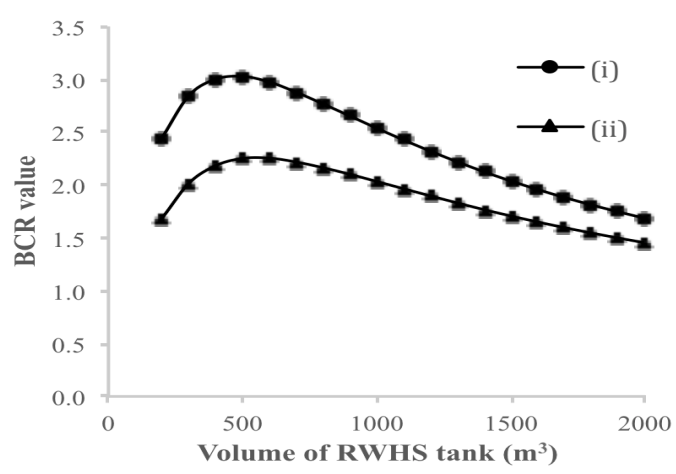

(b)

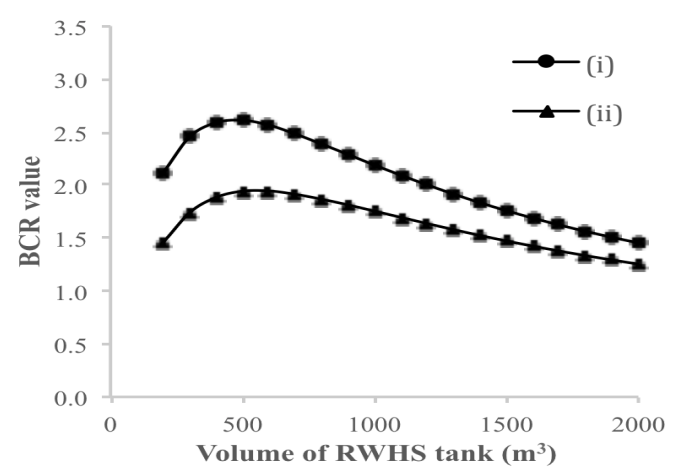

Fig. 7 Analysis of BCR for (i) the RWHS installed during the construction of building and (ii) the RWHS retrofitted after the building operation with the water tariffs of (a) $3.0 \mathrm{RM} / \mathrm{m}^{3}$, (b) $4.0 \mathrm{RM} / \mathrm{m}^{3}$ and (c) $4.7 \mathrm{RM} / \mathrm{m}^{3}$

The results of this study show that the maximum BCR value of $500-\mathrm{m}^{3}$ RWHS tank installed during construction increases by $34.48 \%$ from 1.45 to 1.95 for a water tariff of $3.0 \mathrm{RM} / \mathrm{m}^{3}$ (see Fig. 7a), by $34.54 \%$ from 1.94 to 2.61 for a water tariff of 4.0 $\mathrm{RM} / \mathrm{m}^{3}$ (see Fig. $7 \mathrm{~b}$ ) and by $34.67 \%$ from 2.25 to 3.03 for a water tariff of $4.7 \mathrm{RM} / \mathrm{m}^{3}$ (see Fig. 7c) compared to that retrofitted after operation of AEON Taman Universiti commercial building. The value of BCR higher than 1.0 obtained in the case of RWHS generated cash income could be due to the level of social acceptance related to the affordability and economic profitability of the RWH design can result in the money saving of greater than the total investment cost (Musz-Pomorska et al., 2020). Price of water is a critical factor to be used as the rational policy for implementing the optimal size of RWHS tank installed during the construction of building (Dallman et al., 2016). This revealed that the BCR values of RWHS installed together with building construction are all higher than that retrofitted after building operation. As a conclusion, the implementation of RWHS installed during construction of commercial building could be better than that retrofitted after building operation. To our knowledge at present, the performance analysis of RWHS installed during the construction phase compared to that retrofitted after commercial building operation has not been reported in the literatures. The reliability and economic analysis using two scenarios of RWHS installed during the construction and that retrofitted after the operation of commercial building may contribute to the objective ability of decisionmaker and the quality of decision to ensure a safe design and construction of the future building with a large rooftop area. The finding of this study may provide guideline for constructing an effective RWHS installed at the commercial building 
and generates the valuable information for policymakers and society. The limitations of this study didn't include the analysis of flood risk reduction, rainwater quality and public acceptance of the RWHS implementation to provide a more comprehensive accounting, which could be an overview of other benefits available to the local government and civil society. It may provide an identification of potential topic on the sustainable management of rainwater for the funding opportunity of future research.

\section{Conclusions}

The study evaluated the performance of RWHS installed during the construction and that retrofitted after the operation of AEON Taman Universiti commercial building. The analysis of rainfall patterns and water uses showed that the implementation of RWHS at large rooftop area of building in the southwest part of Peninsular Malaysia is reliable. An increase in the size of RWHS tank reduced the days of empty RWHS tank with a maximum reliability of $94.5 \%$ can be achieved using the RWHS tank of $1000 \mathrm{~m}^{3}$. The economic analysis of using the NPV, ROI and BCR values revealed that the reliability of RWHS installed during the period of construction attractively increased with increasing of the water tariff is economically more feasible than that retrofitted after the operation of commercial building. The reliability and cost-benefit analysis of the RWHS operation may contribute towards the design and construction of the future building in the regions having significant rainfall and in the regions where good quality of surface water or groundwater is lacking. The findings of rainfall data and economic modelling to the analysis of RWHS installation can be used to guide the future researches in the implimentation of RWHS collected rainwater from the large rooftop area of building and provide an insight into the application of RWHS installed in other regions of tropical climate.

\section{References}

Abbas, S., Mahmood, M. J. \& Yaseen, M. (2021). Assessing the potential for rooftop rainwater harvesting and its physio and socioeconomic impacts, Rawal watershed, Islamabad, Pakistan. Environment, Development and Sustainability. https://doi.org/10.1007/s10668-021-01422-z

Alexander, L., Zhang, X., Peterson, T., Caesar, J., Gleason, B., Tank, A. K., Haylock, M., Collins, D., Trewin, B., \& Rahimzadeh, F. (2006). Global observed changes in daily climate extremes of temperature and precipitation. Journal of Geophysical. Research: Atmospheres, 111, D-5. https://doi.org/10.1029/2005JD006290

Al-Salaymeh, A., Al-Khatib, I. A., \& Arafat, H. A. (2011). Towards sustainable water quality: management of rainwater harvesting cisterns in Southern Palestine. Water Resources Management, 25, 1721-1736. https://doi.org/10.1007/s11269-0109771-0

Amos, C. C., Rahman, A., \& Gathenya, J. M. (2018). Economic analysis of rainwater harvesting systems comparing developing and developed countries: A case study of Australia and Kenya. Journal of Cleaner Production, 172, 196-207. https://doi.org/10.1016/j.jclepro.2017.10.114

As-syakur, A.R., Tanaka, T., Osawa, T., \& Mahendra, M.S. (2013). Indonesian rainfall variability observation using TRMM multi-satellite data. International Journal of Remote Sensing, 34(21), 7723-7738. https://doi.org/10.1080/ 01431161.2013.826837

Bashar, M. Z. I., Karim, M. R., \& Imteaz, M. A. (2018). Reliability and economic analysis of urban rainwater harvesting: A comparative study within six major 
cities of Bangladesh. Resources, Conservation and Recycling, 133, 146-154. https://doi.org/10.1016/j.resconrec.2018.01.025

Bernard, B., \& Joyfred, A. (2020). Contribution of rainfall on rooftop rainwater harvesting and saving on the slopes of Mt. Elgon, East Africa. The Scientific World Journal, 2020, 7196342. https://doi.org/10.1155/2020/7196342

Campisano, A., Butler, D., Ward, S., Burns, M. J., Friedler, E., DeBusk, K., FisherJeffes, L. N., Ghisi, E., Rahman, A., Furumai, H., \& Han, M. (2017). Urban rainwater harvesting systems: research, implementation and future perspectives. Water Research, 115, 195-209. https://doi.org/10.1016/j.watres.2017.02.056

Campisano, A., D'Amico, G., \& Modica, C. (2017). Water saving and cost analysis of large-scale implementation of domestic rainwater harvesting in minor Mediterranean islands. Water, 9(12), 916. https://doi.org/10.3390/w9120916

Chilton, J. C., Maidment, G. G., Marriott, D., Francis, A., \& Tobias, G. (2000). Case study of a rainwater recovery system in a commercial building with a large roof. Urban Water, 1(4), 345-354. https://doi.org/10.1016/S1462-0758(00)00032-7

Coombes, P. J., Kuczera, G., Kalma, J. D., \& Argue, J. R. (2002). An evaluation of the benefits of source control measures at the regional scale. Urban Water, 4(4), 307-320. https://doi.org/10.1016/S1462-0758(02)00028-6

Dallman, S., Chaudhry, A. M., Muleta, M. K., \& Lee, J. (2016). The value of rain: Benefit-cost analysis of rainwater harvesting systems. Water Resources Management, 30, 4415-4428. https://doi.org/10.1007/s11269-016-1429-0

Dismas, J., Mulungu, D. M. M., \& Mtalo, F. W. (2018). Advancing rainwater harvesting as a strategy to improve water access in Kinondoni municipality, Tanzania. Water Supply, 18(3), 745-753. https://doi.org/10.2166/ws.2018.007

Domínguez-Barrero, F., \& López-Laborda, J. (2012). Taxation and the saver's choice between a life annuity and a lump sum pension plan payout: The case of Spain. Pensions: An International Journal, 17, 63-69. https://doi.org/10.1057/pm.2012.4

Farreny, R., Gabarrell, X., \& Rieradevall, J. (2011). Cost-efficiency of rainwater harvesting strategies in dense Mediterranean neighbourhoods. Resources, Conservation and Recycling, 55(7), 686-694. https://doi.org/10.1016/ j.resconrec.2011.01.008

Foo, S. W., Mah, D. Y. S., \& Ayu, B. E. (2017). Modelling rainwater harvesting for commercial buildings. Water Pract. Technol, 12(3), 698-705. https://doi.org/ 10.2166/wpt.2017.077

Freni, G., \& Liuzzo, L. (2019). Effectiveness of rainwater harvesting systems for flood reduction in residential urban areas. Water, 11(7), 1389. https://doi.org/ 10.3390/w11071389

Fulazzaky, M. A. (2014). Challenges of integrated water resources management in Indonesia. Water, 6(7), 2000-2020. https://doi.org/10.3390/w6072000

Fulazzaky, M. A., Heryansyah, A., Solaiman, M. H., \& Yusop, Z. (2017). A water balance approach for assessing the potential source of water in Dohuk Dam for agricultural, domestic and tourism purposes. Water Policy, 19(2), 322-340. https://doi.org/10.2166/wp.2016.016

Fulazzaky, M. A., Sunar, N. M., Latiff, A. A. A., \& Kassim, A. H. M. (2009). Empirical models of bio-sand filter to calculate the design parameters. Water Supply, 9(6), 723-734. https://doi.org/10.2166/ws.2009.228

Gado, T.A., \& El-Agha, D.E. (2020). Feasibility of rainwater harvesting for sustainable water management in urban areas of Egypt. Environmental Science and Pollution Research, 27, 32304-32317. https://doi.org/10.1007/s11356-01906529-5 
Hajani, E., \& Rahman, A. (2014). Reliability and cost analysis of a rainwater harvesting system in peri-urban regions of Greater Sydney, Australia. Water, 6(4), 945-960. https://doi.org/10.3390/w6040945

Hervás-Gámez, C., \& Delgado-Ramos, F. (2019). Critical review of the public participation process in drought management plans. The Guadalquivir river basin case in Spain. Water Resources Management, 33, 4189-4200. https://doi.org/10.1007/s11269-019-02354-0

Imteaz, M. A., Shanableh, A., Rahman, A., \& Ahsan, A. (2011). Optimisation of rainwater tank design from large roofs: A case study in Melbourne, Australia. Resources, Conservation and Recycling, 55(11), 1022-1029. https://doi.org/ 10.1016/j.resconrec.2011.05.013

Kim, K., \& Yoo, C. (2009). Hydrological modeling and evaluation of rainwater harvesting facilities: Case study on several rainwater harvesting facilities in Korea. Journal of Hydrologic Engineering, 14(6), 545-561. https://doi.org/ 10.1061/(ASCE)HE.1943-5584.0000030.

Kutlu-Koc, V., Alessie, R., \& Kalwij, A. (2017). Consumption behavior, annuity income and mortality risk of retirees. De Economist 2017, 165, 349-380. https://doi.org/10.1007/s10645-017-9301-z

Lani, N. H. M., Syafiuddin, A., Yusop, Z., Adam, U. B., \& Amin, M. Z. B. M. (2018a). Performance of small and large scales rainwater harvesting systems in commercial buildings under different reliability and future water tariff scenarios. Science of The Total Environment, 636, 1171-1179. https://doi.org/ 10.1016/j.scitotenv.2018.04.418

Lani, N. H. M., Yusop, Z., \& Syafiuddin, A. (2018b). A review of rainwater harvesting in Malaysia: prospects and challenges. Water, 10(4), 506. https://doi.org/ 10.3390/w10040506

Liaw, C. -H., \& Chiang, Y. -C. (2014). Framework for assessing the rainwater harvesting potential of residential buildings at a national level as an alternative water resource for domestic water supply in Taiwan. Water, 6(10), 3224-3246. https://doi.org/10.3390/w6103224

Liaw, C. -H., \& Tsai, Y. -L. (2004). Optimum storage volume of rooftop rainwater harvesting systems for domestic use. Journal of the American Water Resources Association, 40(4), 901-912. https://doi.org/10.1111/j.1752-1688.2004.tb01054.x

Lizárraga-Mendiola, L., Vázquez-Rodríguez, G., Blanco-Piñón, A., Rangel-Martínez, Y., \& González-Sandoval, M. (2015). Estimating the rainwater potential per household in an urban area: case study in Central Mexico. Water, 7(9), 46224637. https://doi.org/10.3390/w7094622

Lopes, V. A. R., Marques, G. F., Dornelles, F., \& Medellin-Azuara, J. (2017). Performance of rainwater harvesting systems under scenarios of non-potable water demand and roof area typologies using a stochastic approach. Journal of Cleaner Production, 148, 304-313. https://doi.org/10.1016/j.jclepro.2017.01.132

Matos, C., Bentes, I., Santos, C., Imteaz, M., \& Pereira, S. (2015). Economic analysis of a rainwater harvesting system in a commercial building. Water Resources Management, 29, 3971-3986. https://doi.org/10.1007/s11269-015-1040-9

Molaei, O., Kouchakzadeh, M., \& Fashi, F. H. (2019). Evaluation of rainwater harvesting performance for water supply in cities with cold and semi-arid climate. Water Supply, 19(5), 1322-1329. https://doi.org/10.2166/ws.2018.193

Molaei, O., Kouchakzadeh, M., \& Fashi, F. H. (2020). Assessing rainwater harvesting systems and reliability analysis of storage tanks: a monitoring study and system 
simulation. Water and Environment Journal, 34, 158-169. https://doi.org/ 10.1111/wej.12514

Morales-Pinzón, T., Lurueña, R., Gabarrell, X., Gasol, C. M., \& Rieradevall, J. (2014). Financial and environmental modelling of water hardness - Implications for utilising harvested rainwater in washing machines. Science of The Total Environment, 470-471, 1257-1271. https://doi.org/10.1016/j.scitotenv.2013.10.101

Mun, J. -S., Kim, H. -N., Park, J. -B., Lee, J. -H., \& Kim, R. -H. (2012). Evaluation of tank capacity of rainwater harvesting system to secure economic feasibility and sensitivity analysis. The Korean Society of Water and Wastewater, 26(2), 191199. https://doi.org/10.11001/jksww.2012.26.2.191

Musz-Pomorska, A., Widomski, M. K., \& Gołebiowska, J. (2020). Financial sustainability of selected rain water harvesting systems for single-family house under conditions of eastern Poland. Sustainability, 12(12), 4853. https://doi.org/ $10.3390 / \mathrm{su} 12124853$

Notaro, V.; Liuzzo, L., \& Freni, G. (2017). Evaluation of the optimal size of a rainwater harvesting system in Sicily. Journal of Hydroinformatics, 19(6), 853864. https://doi.org/10.2166/hydro.2017.150

Oviedo-Ocaña, E. R., Dominguez, I., Ward, S., Rivera-Sanchez, M. L., \& ZarazaPeña, J. M. (2018). Financial feasibility of end-user designed rainwater harvesting and greywater reuse systems for high water use households. Environmental Science and Pollution Research, 25, 19200-19216. https://doi.org/10.1007/s11356-017-8710-5

Pacheco, G. C. R., \& Campos, M. A. S. (2016). Economic feasibility of rainwater harvesting systems: a systematic literature review. Journal of Water Supply: Research and Technology-Aqua, 66(1), 1-14. https://doi.org/10.2166/aqua.2016.048

Palla, A., Gnecco, I., Lanza, L., \& La Barbera, P. (2012). Performance analysis of domestic rainwater harvesting systems under various European climate zones. Resources, Conservation and Recycling, 62, 71-80. https://doi.org/10.1016/ j.resconrec.2012.02.006

Park, D., \& Um, M. -J. (2018). Sustainability index evaluation of the rainwater harvesting system in six US Urban Cities. Sustainability, 10(1), 280. https://doi.org/10.3390/su10010280

Plappally, A. K., \& Lienhard V, J. H. (2013). Costs for water supply, treatment, enduse and reclamation. Desalin. Water Treat, 51(1-3), 200-232. https://doi.org/ 10.1080/19443994.2012.708996

Rahman, A., Keane, J., \& Imteaz, M.A. (2012). Rainwater harvesting in Greater Sydney: Water savings, reliability and economic benefits. Resources, Conservation and Recycling, 61, 16-21. https://doi.org/10.1016/j.resconrec. 2011.12.002

Rahman, S., Khan, M. T. R., Akib, S., Din, N. B. C., Biswas, S. K., \& Shirazi, S. M. (2014). Sustainability of rainwater harvesting system in terms of water quality. The Scientific World Journal, 2014, 721357. https://doi.org/10.1155/2014/721357

Raimondi, A., \& Becciu, G. (2014). Probabilistic modeling of rainwater tanks. Procedia Engineering, 89, 1493-1499. https://doi.org/10.1016/j.proeng.2014.11.437

Saeedi, I., \& Goodarzi, M. (2020). Rainwater harvesting system: a sustainable method for landscape development in semiarid regions, the case of Malayer University campus in Iran. Environment, Development and Sustainability, 22, 1579-1598. https://doi.org/10.1007/s10668-018-0218-8 
Sanches Fernandes, L. F., Terêncio, D. P. S., \& Pacheco, F. A. L. (2015). Rainwater harvesting systems for low demanding applications. Science of The Total Environment, 529, 91-100. https://doi.org/10.1016/j.scitotenv.2015.05.061

Sepehri, M., Malekinezhad, H., Ilderomi, A. R., Talebi, A., \& Hosseini, S. Z. (2018). Studying the effect of rain water harvesting from roof surfaces on runoff and household consumption reduction. Sustainable Cities and Society, 43, 317-324. https://doi.org/10.1016/j.scs.2018.09.005

Sendanayake, S., Miguntanna, N. P., \& Jayasinghe, M. T. R. (2014). Validation of design methodology for rainwater harvesting for tropical climates. Asian Journal of Water, Environment and Pollution, 11(1), 87-93.

Sheikh, V. (2020). Perception of domestic rainwater harvesting by Iranian citizens. Sustainable Cities and Society, 60, 102278. https://doi.org/10.1016/j.scs.2020.102278

Shokati, H., Kouchakzadeh, M., \& Fashi, F. H. (2020). Assessing reliability of rainwater harvesting systems for meeting water demands in different climatic zones of Iran. Modeling Earth Systems and Environment, 6, 109-114. https://doi.org/10.1007/s40808-019-00662-3

Stec, A., \& Zelenáková, M. (2019). An analysis of the effectiveness of two rainwater harvesting systems located in Central Eastern Europe. Water, 11(3), 458. https://doi.org/10.3390/w11030458

Su, M. -D., Lin C. -H., Chang, L. -F., Kang, J. -L., \& Lin, M. -C. (2009). A probabilistic approach to rainwater harvesting systems design and evaluation. Resources, Conservation and Recycling, 53(7), 393-399. https://doi.org/ 10.1016/j.resconrec.2009.03.005

Suhaila, J., \& Jemain, A.A. (2012). Spatial analysis of daily rainfall intensity and concentration index in Peninsular Malaysia. Theoretical and Applied Climatology, 108, 235-245. https://doi.org/10.1007/s00704-011-0529-2

Suhaila, J., \& Yusop, Z. (2017). Spatial and temporal variabilities of rainfall data using functional data analysis. Theoretical and Applied Climatology, 129, 229242. https://doi.org/10.1007/s00704-016-1778-X

Tam, V. W. Y., Tam, L., \& Zeng, S. X. (2010). Cost effectiveness and tradeoff on the use of rainwater tank: An empirical study in Australian residential decisionmaking. Resources, Conservation and Recycling, 54(3), 178-186. https://doi.org/10.1016/j.resconrec.2009.07.014

Terêncio, D. P. S., Sanches Fernandes, L. F., Cortes, R. M. V., Moura, J. P., \& Pacheco, F. A. L. (2018). Rainwater harvesting in catchments for agro-forestry uses: A study focused on the balance between sustainability values and storage capacity. Science of The Total Environment, 613-614, 1079-1092. https://doi.org/10.1016/j.scitotenv.2017.09.198

Terêncio, D. P. S., Sanches Fernandes, L. F., Cortes, R. M. V., \& Pacheco, F. A. L. (2017). Improved framework model to allocate optimal rainwater harvesting sites in small watersheds for agro-forestry uses. Journal of Hydrology, 550, 318-330. https://doi.org/10.1016/j.jhydrol.2017.05.003

Turkyilmaz, A., Guney, M., Karaca, F., Bagdatkyzy, Z., Sandybayeva, A., \& Sirenova, G. (2019). A comprehensive construction and demolition waste management model using PESTEL and 3R for construction companies operating in Central Asia. Sustainability, 11(6), 1593. https://doi.org/ 10.3390/su11061593

Umapathi, S., Pezzaniti, D., Beecham, S., Whaley, D., \& Sharma, A. (2019). Sizing of domestic rainwater harvesting systems using economic performance 
indicators to support water supply systems. Water, 11(4), 783. https://doi.org/ $10.3390 / \mathrm{w} 11040783$

Ward, S., Memon, F. A., \& Butler, D. (2012). Performance of a large building rainwater harvesting system. Water Research, 46(16), 5127-5134. https://doi.org/10.1016/j.watres.2012.06.043

Wong, C.L., Liew, J., Yusop, Z., Ismail, T., Venneker, R., \& Uhlenbrook, S. (2016). Rainfall characteristics and regionalization in Peninsular Malaysia based on a high resolution gridded data set. Water, 8(11), 500. https://doi.org/10.3390/ w8110500

Zavala, M. A. L., Prieto, M. J. C., Rojas, C. A. R. (2018). Rainwater harvesting as an alternative for water supply in regions with high water stress. Water Supply, 18(6), 1946-1955. https://doi.org/10.2166/ws.2018.018 